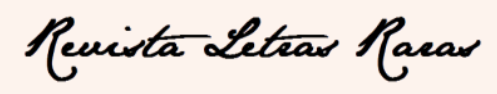

ISSN: 2317-2347 - v. 7, Edição Especial (2018)

\title{
REVISORES DE LÍNGUA INGLESA
}

\section{Ana Paula Herculano}

Graduanda em Letras-Inglês pela Universidade Federal de Campina Grande - Campus Campina Grande, Técnica em Petróleo e Gás pelo Instituto Federal de Educação, Ciência e Tecnologia da Paraíba - Campus Campina Grande. Interesse acadêmico voltado para o estudo de literatura Inglesa.

\section{Link Currículo Lattes: http://lattes.cnpq.br/0611404479709721}

\section{Janailton Mick Vitor da Silva}

Mestre em Estudos da Tradução pela Universidade de Brasília (UnB). Licenciado em Letras - Língua Inglesa pela Universidade Federal de Campina Grande (UFCG). Tem experiência na área de Letras e Estudos da Tradução, atuando nos seguintes temas: Tradução Audiovisual, Linguística de Corpus, Estudos da Tradução Baseados em Corpus e Ensino de Inglês como Língua Estrangeira.

\section{Link Currículo Lattes: http://lattes.cnpq.br/7656706746044637}

\section{Jhuliane Evelyn da Silva}

Doutoranda em Letras pela Universidade Federal do Paraná, na área de concentração Estudos Linguísticos, linha de pesquisa Linguagens, culturas e identidades: ensino e aprendizagem. Mestre pelo programa de Pós-Graduação em Linguagem e Ensino, linha de pesquisa Ensino de Línguas Estrangeiras. Graduada em Letras, com habilitação em Língua Inglesa e suas Respectivas Literaturas no Departamento de Letras Estrangeiras, da Universidade do Estado do Rio Grande do Norte. Participou do Programa Fulbright Language Teacher Assistant no ano 2015-2016 com bolsa Capes/Fulbright na Brown University, EUA. Atualmente participa dos Grupos Identidade e Leitura e Formação de Professores em Línguas Estrangeiras na UFPR. Possui experiência na área de Linguística Aplicada, atuando principalmente nos seguintes temas: Letramento crítico de viés pósestruturalista, Formação de professores, Ensino de Inglês, Pós-modernidade. 


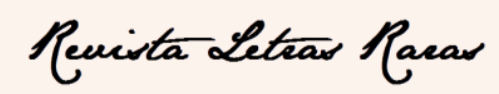

ISSN: 2317-2347 - v. 7, Edição Especial (2018)

Link Currículo Lattes: http://lattes.cnpq.br/3758141059477625

\section{Jorge Alves Pinto}

Cursa o $6^{\circ}$ período do curso de Licenciatura em Letras- língua Inglesa na Universidade Federal de Campina Grande (UFCG). Atuou como monitor do curso de Letras - Português em dois semestres seguidos, a saber 2017.1 e 2017.2. Atualmente é professor bolsista pelo Programa Idiomas sem Fronteiras - Inglês. Tem interesse em pesquisas sobre os estudos de Letramentos e de Literatura e suas implicações para o ensino de Língua Inglesa.

Link Currículo Lattes: http://lattes.cnpq.br/4817632965727076

\section{Laryssa Barros Araújo}

Mestranda no Programa de Pós-graduação em Letras da Universidade Federal de Pernambuco (UFPE). Possui graduação em Letras Inglês pela Universidade Federal de Campina Grande (2016). Participa do Grupo de Pesquisa LACELI (CNPq) (Linguagem, Ação, Crítica e Educação de Línguas. Compõe a equipe técnica da Revista Letras Raras (UFCG). Tem experiência na área de Linguística Aplicada e Textual, Literatura, Revisão e Edição de texto em revista.

Link Currículo Lattes: http://lattes.cnpq.br/3033702449248218

\section{Magnólia de Negreiros Cruz}

Possui Pós-Graduação (Mestrado) em Linguagem e Ensino (Literatura e Ensino) pela Universidade Federal de Campina Grande, graduação em Licenciatura em Letras (Língua e Literatura Inglesa, Língua Vernácula e Literatura) pela Universidade Federal de Campina Grande e graduação em Bacharelado em Arte e Mídia pela Universidade Federal de Campina Grande. Realiza trabalhos de ensino e pesquisa na área de Artes Visuais (fotografia, cinema) e em Literatura (brasileira, estrangeira, metodologias de ensino). Tem experiência na área de Letras, com ênfase no ensino de Literatura e Língua Inglesa; e na área de Artes em Fotografia, Cinema e outras Artes Visuais.

\section{Link Currículo Lattes: http://lattes.cnpq.br/8899209732208087}




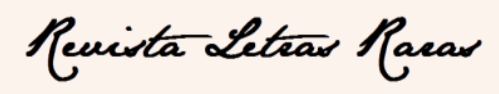

ISSN: 2317-2347 - v. 7, Edição Especial (2018)

\section{Paula Sousa Costa}

Mestre em Linguagem e Ensino no Programa de Pós-graduação da UFCG, especialista pela FASP - PB em Língua e literatura, e graduada pela UECE em Língua Portuguesa/ Inglesa. Tem experiência na área de Letras, com ênfase em Língua Inglesa e Literaturas, atuando principalmente nas áreas: literatura africana de língua inglesa e a abordagem do texto literário na aula de língua estrangeira.

Link Currículo Lattes: http://lattes.cnpq.br/1161094584307461

\section{Rossana Paulino de Luna}

Mestranda em Linguagem e Ensino no Programa de Pós-Graduação em Linguagem e Ensino (Pós-LE) da UFCG. Licenciada em Letras - Língua Inglesa pela Universidade Federal de Campina Grande (UFCG) (2011-2016). Trabalhou como Professora do NucLI (Inglês sem Fronteiras) da UFCG (2015-2016). Atuou como Monitora bolsista das disciplinas Teoria do Texto Poético e Teoria da Narrativa (2011.2 e 2012.1). Foi bolsista do Programa de Educação Tutorial do curso de Letras (PET - Letras) (2012-2015) (CAPES) (MEC/SESu) da UFCG. Seus interesses de pesquisa voltam-se para: i) Estudos da Tradução (tradução audiovisual, tradução intersemiótica e cinema); ii) Literatura comparada.

\section{Link Currículo Lattes: http://lattes.cnpq.br/3871127988717094}

\section{Walter Vieira Barros}

Mestrando do Programa de Pós-Graduação em Linguagem e Ensino (PPGLE) da Universidade Federal de Campina Grande (UFCG). Licenciado em Letras - Língua Inglesa pela Universidade Federal de Campina Grande (UFCG). Detém a atenção para os estudos sobre Ensino-Aprendizagem de Língua Inglesa, Formação de Professores de Língua Inglesa e Letramentos (Novos Letramentos, Multiletramentos, Letramento Crítico e Letramentos Digitais).

Link Currículo Lattes: http://lattes.cnpq.br/6670033484989283 